\title{
LIMB-GIRDLE MUSCULAR DYSTROPHY
}

\section{An immunohistochemical diagnostic approach}

\author{
Enio Alberto Comerlato, Rosana Hermínia Scola, Lineu César Werneck
}

\begin{abstract}
The limb-girdle muscle dystrophy (LGMD) represents a heterogeneous group of muscular diseases with dominant and recessive inheritance, individualized by gene mutation. A group of 56 patients, 32 males and 24 females, with suggestive LGMD diagnosis were submitted to clinical evaluation, serum muscle enzymes, electromyography, muscle biopsy, and the immunoidentification (ID) of sarcoglycans (SG) $\alpha, \beta, \gamma$ and $\delta$, dysferlin and western blot for calpain-3. All the patients had normal ID for dystrophin (rod domain, carboxyl and amine terminal). The $\alpha$-SG was normal in 42 patients, $\beta$-SG in $28, \beta$-SG in $45, \delta$-SG in 32 , dysferlin in 37 and calpain-3 in 9. There was a reduction in the $\alpha$-SG in 7 patients, $\beta$-SG in 4, $\gamma$-SG in 2, and $\delta$-SG in 8 . There was deficiency of $\alpha$-SG in 7 patients, $\beta$-SG in $6, \gamma$-SG in $9, \delta$-SG in 5 , dysferlin in 8 , and calpain-3 in 5 . The patients were grouped according the ID as sarcoglycans deficiency 18 cases, dysferlin deficiency 8 cases and calpain-3 deficiency 5 cases. Only the sarcoglycans deficiency group showed calf hypertrophy. The dysferlin deficiency group was more frequent in females and the onset was later than sarcoglycan and calpain-3 deficiency groups. The calpain-3 deficiency group occurred only in males and showed an earlier onset and weaker muscular strength.
\end{abstract}

KEY WORDS: limb-girdle muscular dystrophy, immunoidentification, sarcoglycans, dysferlin, calpain-3.

\section{Distrofias musculares de cinturas: uma abordagem diagnóstica imuno-histoquímica}

RESUMO - As distrofias musculares de cinturas (DMC) representam grupo heterogêneo de doenças musculares com heranças autossômicas dominante ou recessivas, caracterizadas geneticamente por mutações gênicas específicas. Cinqüenta e seis pacientes, 32 masculinos e 24 femininos, com diagnóstico sugestivo de DMC, foram submetidos a avaliação clínica, dosagem séricas das enzimas musculares, eletromiografia, biópsia muscular e imunoidentificação (ID) das proteínas sarcoglicanas (SG) $\alpha, \beta, \gamma$ e $\delta$, disferlina e calpaína-3. A ID da distrofina (domínio rod e terminais carboxila e amino) era normal em todos os pacientes. Apresentaram ID normal para $\alpha$-SG 42 casos, $\beta$-SG 28, $\gamma$,-SG 45, $\delta$-SG 32, disferlina 37 e calpaína-3 9. Foi observada redução de $\alpha$-SG em 7 pacientes, $\beta$-SG em 4, $\gamma$-SG em 2 e $\delta$-SG em 8 . Houve deficiência de $\alpha$-SG em 7 pacientes, $\beta$-SG em $6, \gamma$-SG 9, $\delta$-SG em 5 , disferlina em 8 e calpaína-3 em 5 . Os pacientes foram classificados de acordo com a ID em deficiência de SG em 18 casos, disferlina em 8 e calpaína-3 em 5 . A hipertrofia de panturrilhas foi observada apenas no grupo com deficiência de SG. O grupo com deficiência de disferlina teve maior número de mulheres acometidas e a idade de início dos sintomas foi mais tardio em relação aos grupos com deficiência de SG e calpaína-3. O grupo com deficiência de calpaína-3 ocorreu apenas em pacientes do sexo masculino, a idade do início dos sintomas foi menor e teve maior fraqueza muscular.

PALAVRAS-CHAVE: distrofias musculares de cinturas, imunoidentificação, sarcoglicano, disferlina, calpaína-3.

The cytogenetic localization of the gene of the Duchenne muscular dystrophy (DMD) in the short arm of chromosome $\mathrm{X}^{1}$, locus $\mathrm{Xp2} 1^{2}$, with posterior cloning of the DNA ${ }^{3}$, codification ${ }^{4}$ and identification of the gene product, dystrophin ${ }^{5}$ and subsequent characterization of the dystrophin glycopro- tein complex (DGC) ${ }^{6,7}$ have brought great advances in the briefing of molecular pathogeneses of muscular dystrophies. The DGC is a multisubunit complex of proteins, which form a structural linkage between the cytoskeleton ( $\mathrm{F}$-actin) and the extracellular matrix (laminin- $\alpha 2)^{8}$. The integral proteins

Neuromuscular/Neurology Division, Internal Medicine Departament, Hospital de Clínicas da Universidade Federal do Paraná, Curitiba PR, Brazil (UFPR). Supported: Fundação Araucária and CAPES.

Received 7 June 2004, received in final form 10 November. Accepted 25 November 2004.

Dr. Lineu Cesar Werneck - Hospital de Clínicas da UFPR - Rua Gal. Carneiro 181/3º andar - 80060-900 Curitiba PR - Brazil. E-mail: werneck@hc.ufpr.br 
that comprise the DGC are structurally organized into sub-complexes, formed by the dystrophin, the dystroglycan complex ( $\alpha$ and $\beta$ subunits), the sarcoglycan (SG) complex ( $\alpha, \beta, \gamma, \delta$ and $\varepsilon$ subunits), $\alpha$-dystrobrevin, syntrophins and sarcospan ${ }^{9}$. At least six forms of muscular dystrophy arise from primary mutations in genes encoding components of this complex ${ }^{10,11}$. With the identification of these genes and their product, the limb-girdle muscular dystrophies (LGMD) where classified in autosomal dominant (LGMD1) and recessive (LGMD2). Pathogenic mutations in the SG complex components determine a group of autosomal recessive limb girdle muscular dystrophies (LGMD2) known as sarcoglycanopathies: the $\gamma, \alpha, \beta$ and $\delta$ sarcoglycanopathy, genetically classified as LGMD2C ${ }^{12}, 2 \mathrm{D}^{13}, 2 \mathrm{E}^{14}$ and $2 \mathrm{~F}^{15}$ respectively. The sarcoglycanopathies present a variable clinical features and is characterized by the biochemical deficiency of its subunits, independently of any primary gene defects ${ }^{16}$.

Among the LGMD where expression of sarcoglycans is normal, other genes are involved, that can cause defects or deficiencies in sarcolemmal proteins: dysferlin (LGMD2B) ${ }^{17}$, caveolin-3 (autosomal dominant limb girdle muscular dystrophy LGMD1C) ${ }^{18}$; cytoplasmatic proteases: calpain-3 $(\text { LGMD2A })^{19}$; cytoplasmatic proteins associated with organelles: TRIM32 (LGMD2H) ${ }^{20}$, fukutin related protein (FKRP) (LGMD2I)21; sarcomeric proteins: telethonin (LGMD2G) ${ }^{22}$, titin (LGMD2J) ${ }^{23}$, myotilin $(\text { LGMD1A })^{24}$, filamin C (LGMD1F) ${ }^{25}$; and nuclear membrane proteins: lamin A/B (LGMD1B) ${ }^{26}$.

Therefore, the limb-girdle muscular dystrophy (LGMD) becomes a clinically and genetically heterogeneous group of degenerative muscular diseases where the clinical, laboratory, electromyographic, histopathological and immunohistochemical have turned to be of great importance in the guideline of the specific genetic study. These made us to carry through this work, with the intention to improve the diagnosis in a heterogeneous group of patients with LGMD.

\section{METHOD}

We selected 56 patients with LGMD diagnostic and normal dystrophin by immunofluorescence (rod domain, carboxy and amino terminal) admitted to the Neuromuscular Unit, from January 1976 to May 2001. The patients were submit to clinical evaluation, serum muscle enzymes, electromyography, muscle biopsy, and the immunoidentification (ID) of $\alpha$-sarcoglycan, $\beta$ - sarcoglycan, $\gamma$-sarcoglycan, $\delta$-sarcoglycan, dysferlin and calpain-3.
Clinical evaluation - We collected data regarding gender distribution, family history, age and mode of onset, muscle strength, muscle atrophy and hypertrophy, functional abilities, and progression of the disease. To assess muscle strength we used a manually muscle testing of the British Medical Research Council (MRC) scale converted to $0-7$ point system as follows: $0=0,1=1,2=2,3=3,4(-)=4$, $4=5,4(+)=6,5=7^{27}$. The proximal and distal muscles of the upper and lower limbs were tested. The functional grade was classified the Vignos and Archibald scale ${ }^{28}$.

Muscle enzymes - The serum muscle enzymes activity to creatine kinase (CK) was performed in 49 cases, lactic dehydrogenase (LDH) in 25 cases, alanine aminotransferase (ALT) in 40 cases, aspartate aminotransferase (AST) in 25 cases and aldolase in 19 cases. The plasmatic levels were registered as time fold increased above the normal limit.

Electromyography - The electromyography (EMG) was performed in 50 patients and was classified as normal, myopathic, and mixed.

Muscle biopsy - Open muscle biopsies were taken from deltoid, biceps or quadriceps. All samples were frozen in liquid nitrogen and cryostat sections stained histologically and histochemically according to standard procedures ${ }^{29}$. The following features were assessed: variation in muscle fiber diameter, the distribution of atrophied and hypertrophied fibers; fiber degeneration and regeneration processes, architectural changes, connective and fat tissue increase and inflammatory changes.

Immunocytochemistry - Indirect immunofluorescence microscopy of $4 \mu$ cryosections from skeletal muscle biopsy specimens was performed ${ }^{30}$. The samples were incubated against monoclonal antibodies to $\alpha$-SG diluted 1:20 (Novocastra NCL-50DAG, Newcastle upon Tyne, UK), $\beta$-SG diluted 1:100 (Novocastra NCL-b-SARC, Newcastle upon Tyne, UK), $\gamma$-SG diluted 1:10 (Novocastra NCL-g-SARC, Newcastle upon Tyne, UK), $\delta$-SG diluted 1:25 (Novocastra NCL-d-SARC, Newcastle upon Tyne, UK), and dysferlin diluted 1:10 (Novocastra/NCL-Hamlet, Newcastle upon Tyne, UK). The immunofluorescence to $\alpha$-SG e $\gamma$-SG was realized in all muscle samples, and to $\beta$-DG in 48 , to $\delta$-SG and dysferlin in 45 , and to $\beta$-SG in 38 . The primary antibodies were detected with an appropriate biotinylated secondary antibody diluted 1:500 (Amershem/RPN 1025, Little Chalfont, UK), followed by streptavidin conjugated to flourescein (Amershem/RPN 1232, Little Chalfont, UK, 1:1000). The immunofluorescence intensity was classified as: $0=$ absent: no labeling on any muscle fibers; $+=$ traces: faint fluorescence on occasional fibers; majority of fibers negative; $++=$ reduced: moderately and uniformly decrease fluorescence; $+++=$ normal: uniformly intensity fluorescence. The im- 
munofluorescence to dysferlin was deficient only when the fluorescence was absent.

Western blot - The western blot was performed in patients with normal labeling to $\alpha$-SG, $\beta$-SG, $\gamma$-SG, $\delta$-SG, and dysferlin. Only thirteen muscles samples were available. The muscle proteins were extracted in treatment buffer containing $0.125 \mathrm{~mol} / \mathrm{l}$ Tris-HCL buffer $\mathrm{pH}$ 6.4, $10 \%$ glycerol, $4 \%$ SDS, $4 \mathrm{~mol} / / \mathrm{l}$ urea, $10 \%$ mercaptoethanol and $0.001 \%$ bromophenol blue (final $\mathrm{pH}$ of the treatment buffer was 6.8). Soluble proteins were separated using a SDS-PAGE gel $10 \%$ and the transferred into nitrocellulose membrane. The visualization of blotted proteins nitrocellulose strips were blocked in $5 \%$ milk powder in a pH 8 buffer containing $10 \mathrm{mmol} / \mathrm{l}$ Tris-HCL, $0.15 \mathrm{~mol} / \mathrm{l}$ $\mathrm{NaCl}$ and $0.05 \%$ Tween 20 (TBST). Blots were probed with antibodies against to calpain-3 diluted 1:100 (Novocastra/NCL-12A2, Newcastle upon Tyne, UK) and visualized using peroxidase-conjugated anti-mouse secondary antibody diluted 1:1000 (Amersham/NA931, Little Chalfont, UK) followed by exposure to freshly prepared $0.05 \%$ diaminobenzidine and $0.1 \% \mathrm{H}_{2} \mathrm{O}_{2}{ }^{31}$. Only the absence of band to calpain-3 was considered deficient.

Statistical analysis - Chi-square and Mann-Whitney tests were used to analyze the relation between the presences of abnormalities in the ID groups.

\section{RESULTS}

The $\alpha$-SG was normal in 42 patients, $\beta$-SG in 28, $\gamma$-SG in 45, $\delta$-SG in 32, dysferlin in 37 and calpain3 in 9. There was a reduction in the $\alpha$-SG in 7 patients, $\beta$-SG in 4, $\gamma$-SG in 2 , and $\delta$-SG in 8 . There was deficiency of $\alpha$-SG in 7 patients, $\beta$-SG in $6, \gamma$-SG in $9, \delta$-SG in 5, and dysferlin in 8. The calpain-3 was absent in 5 patients (Table 1).

The patients were classified according to the type of protein deficiency. The Group A, characterized by reduction or deficiency of one or several the SG-complex, was reported in 18 patients (Fig 1); group $B$, characterized by dysferlin deficiency, in 8 (Fig 2); group C with calpain-3 deficiency in 5 (Figs 3 and 4). The group D, not classified, did not show any deficiency. The group E with 17 cases had a non-conclusive evaluation due to insufficient material for the tests and was not included in the statistical analysis (Table 1).

Clinical evaluation - Both male and female patients were affected, with a preponderance of male patients. There was a significant statistical relevance among the groups with dysferlin and calpain-3 deficiency $(p=0.005)$.
Most of patients were sporadic cases. Patients with family history and, or consanguinity of the parents were more common in the dysferlin deficiency group (Table 2), but without statistical significance $(p>0.05)$. An autosomal dominant pattern was observed only in a female patient of group $D$.

The mean age of onset and at evaluation was significantly higher in dysferlin deficiency group (group B) than among sarcoglycans $(p=0.014)$ and calpain-3 ( $p=0.010$ ) deficiency groups (Table 3 ). The diseases duration do not showed statistical significance among the ID groups ( $p>0.05$ ).

The symptoms at presentation occurred by weakness of the muscles of the lower limbs in 29 patients, upper limbs in 6 and both in 4 (Table 3). No statistical difference occurred among the ID groups ( $p>0.05$ ).

The proximal muscle atrophy was observed in all ID groups. Only the dysferlin deficiency group (group B) does not showed distal muscle atrophy (Table 4). Facial weakness occurred in all the groups of ID. In the sarcoglycanopathy group it was observed only in the cases with specific deficiency of $\gamma$-SG. The calf hypertrophy was observed in 4 patients with SG complex deficiency. The calpain-3 deficiency group (group C) presented the lowest muscle strength tests, but without statistical significance. The waddling gait and Gowers sign were commons features in all ID groups. The loss of gait occurred only in SG complex deficiency (group A) and the non-classified (group D) patients. Most of patients showed at evaluation gait impairment, difficulties in running or climbing stairs (Table 4).

Muscle enzymes - The mean elevation of CK and AST in the serum was more expressive in dysferlin deficiency patients; and of LDH, ALT and aldolase in SG complex deficiency patients, but without statistical significance (Table 5).

Electromyography - The myopathic electromyographic pattern was a common finding, observed in 31 patients, but the neuromyopathic pattern occurred in all ID groups (Table 6).

Muscle biopsy - Histopathology- Fiber size variation was encountered in $38(97.1 \%)$ of muscles specimens. Type 1 and 2 fiber atrophy and hypertrophy were more frequent in the calpain-3 deficiency (group A). Scattered angulated fibers were seen in $24(61.5 \%)$ of specimens, and were more common in calpain-3 deficiency group (group A). 
Table 1. Immunocytochemical and western blot analysis.

\begin{tabular}{|c|c|c|c|c|c|c|}
\hline Cases & $\alpha$-SG & $\beta$-SG & $\gamma$-SG & $\delta$-SG & Dysferlin & Calpain-3 \\
\hline \multicolumn{7}{|c|}{ Group A - 18 patients $(32,1 \%)$} \\
\hline 1 & ++ & ND & +++ & +++ & +++ & ND \\
\hline 2 & ++ & ND & +++ & ND & ND & ND \\
\hline 3 & ++ & ND & +++ & +++ & +++ & ND \\
\hline 4 & ++ & +++ & +++ & +++ & +++ & ND \\
\hline 5 & + & ND & 0 & +++ & +++ & ND \\
\hline 6 & ++ & +++ & 0 & ++ & +++ & +++ \\
\hline 7 & +++ & +++ & +++ & ++ & +++ & ND \\
\hline 8 & +++ & +++ & +++ & ++ & +++ & ND \\
\hline 9 & 0 & 0 & 0 & 0 & +++ & ND \\
\hline 10 & + & 0 & + & + & +++ & ND \\
\hline 11 & + & ++ & + & ++ & +++ & ND \\
\hline 12 & 0 & 0 & 0 & 0 & +++ & ND \\
\hline 13 & ++ & + & + & ++ & +++ & ND \\
\hline 13 & + & 0 & 0 & + & +++ & ND \\
\hline 15 & + & + & + & + & +++ & ND \\
\hline 16 & +++ & ++ & +++ & ++ & +++ & ND \\
\hline 17 & ++ & ++ & ++ & ++ & +++ & ND \\
\hline 18 & +++ & ++ & ++ & ++ & +++ & ND \\
\hline
\end{tabular}

Group B -8 patients $(14,3 \%)$

$\begin{array}{llllllll}19 & +++ & +++ & +++ & +++ & 0 & \text { ND } \\ 20 & +++ & +++ & +++ & +++ & 0 & \text { ND } & \text { ND } \\ 21 & +++ & +++ & +++ & +++ & 0 & \text { ND } \\ 22 & +++ & +++ & +++ & +++ & 0 & \text { ND } \\ 23 & +++ & +++ & +++ & +++ & 0 & \text { ND } \\ 24 & +++ & +++ & +++ & +++ & 0 & \text { ND } \\ 25 & +++ & +++ & +++ & +++ & 0 & 0 & \text { ND }\end{array}$

Group C -5 patients $(8,9 \%)$

\begin{tabular}{|c|c|c|c|c|c|c|}
\hline 27 & +++ & +++ & +++ & +++ & +++ & 0 \\
\hline 28 & +++ & +++ & +++ & +++ & +++ & 0 \\
\hline 29 & +++ & +++ & +++ & +++ & +++ & 0 \\
\hline 30 & +++ & +++ & +++ & +++ & +++ & 0 \\
\hline 31 & +++ & +++ & +++ & +++ & +++ & 0 \\
\hline \multicolumn{7}{|c|}{ Group D - 8 patients $(14,3 \%)$} \\
\hline 32 & +++ & +++ & +++ & +++ & +++ & +++ \\
\hline 33 & +++ & +++ & +++ & +++ & +++ & +++ \\
\hline 34 & +++ & ND & +++ & +++ & +++ & +++ \\
\hline 35 & +++ & +++ & +++ & +++ & +++ & +++ \\
\hline 36 & +++ & +++ & +++ & +++ & +++ & +++ \\
\hline 37 & +++ & +++ & +++ & +++ & +++ & +++ \\
\hline 38 & +++ & ND & +++ & +++ & +++ & +++ \\
\hline 39 & +++ & ND & +++ & +++ & +++ & +++ \\
\hline
\end{tabular}

Group E - 17 patients $(30,4 \%)$

\begin{tabular}{|c|c|c|c|c|c|c|}
\hline 40 & +++ & +++ & +++ & +++ & +++ & ND \\
\hline 41 & +++ & +++ & +++ & +++ & +++ & ND \\
\hline 42 & +++ & +++ & +++ & +++ & +++ & ND \\
\hline 43 & +++ & +++ & +++ & +++ & +++ & ND \\
\hline 44 & +++ & +++ & +++ & +++ & +++ & ND \\
\hline 45 & +++ & +++ & +++ & +++ & +++ & ND \\
\hline 46 & +++ & +++ & +++ & +++ & +++ & ND \\
\hline 47 & +++ & ND & +++ & ND & ND & ND \\
\hline 48 & +++ & ND & +++ & ND & ND & ND \\
\hline 49 & +++ & ND & +++ & ND & ND & ND \\
\hline 50 & +++ & ND & +++ & ND & ND & ND \\
\hline 51 & +++ & ND & +++ & ND & ND & ND \\
\hline 52 & +++ & ND & +++ & ND & ND & ND \\
\hline 53 & +++ & ND & +++ & ND & ND & ND \\
\hline 54 & +++ & ND & +++ & ND & ND & ND \\
\hline 55 & +++ & ND & +++ & ND & ND & ND \\
\hline 56 & +++ & ND & +++ & ND & ND & ND \\
\hline
\end{tabular}

0, absent; +, traces; ++ , reduction; +++, normal; ND , not done; group A , sarcoglycanopathy; group B , dysferlinopathy; group $C$, calpainopathy; group $D$, not classified; group $E$, non conclusive. 
Table 2. Gender and family history by immunoidentification groups.

\begin{tabular}{lccccc}
\hline Immunoidentification groups & A & B & C & D & Total \\
\hline Number of patients & 18 & 8 & 5 & 8 & 39 \\
$\quad$ Female & 8 & 7 & - & 3 & 18 \\
Male & 10 & 1 & 5 & 5 & 21 \\
Family history & 7 & 5 & 2 & 4 & 18 \\
\hline
\end{tabular}

A, sarcoglycanopathy; B, dysferlinopathy; C, calpainopathy; D, not classified.

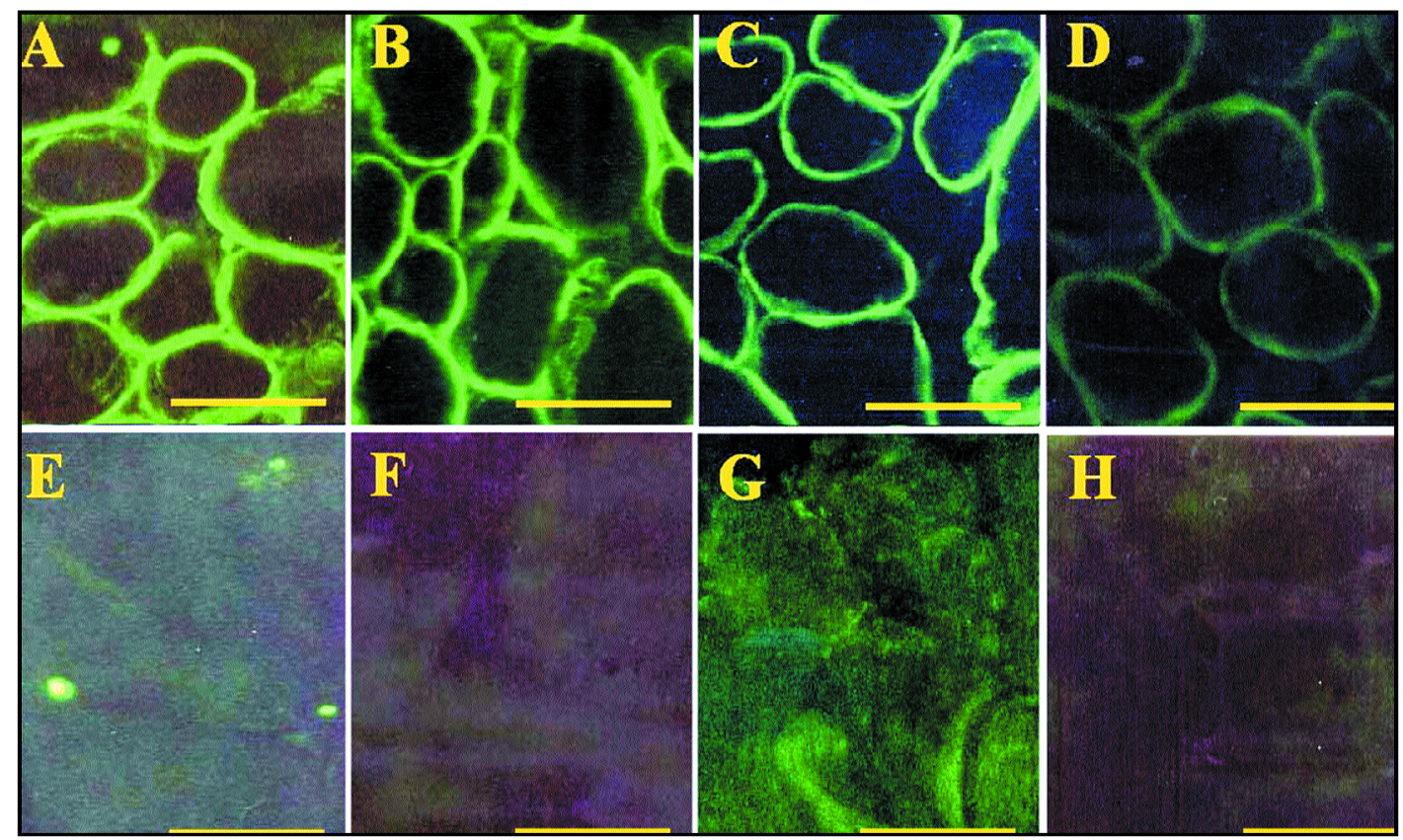

Fig 1. Sarcoglycan deficiency (Case 12, immunofluorescence). A, Dystrophin carboxyl terminal; B, Dystrophin amino terminal; C, Dystrophin Rod domain; D, Dyspherlin; $E$, $\alpha$-Sarcoglycan; $F, \beta$-Sarcoglycan; $G, \gamma$-Sarcoglycan; $H$, $\delta$-Sarcoglycan. (Bar $100 \mu$ in $A, B, C, D ; 25 \mu$ in $E, F, G, H$ ).

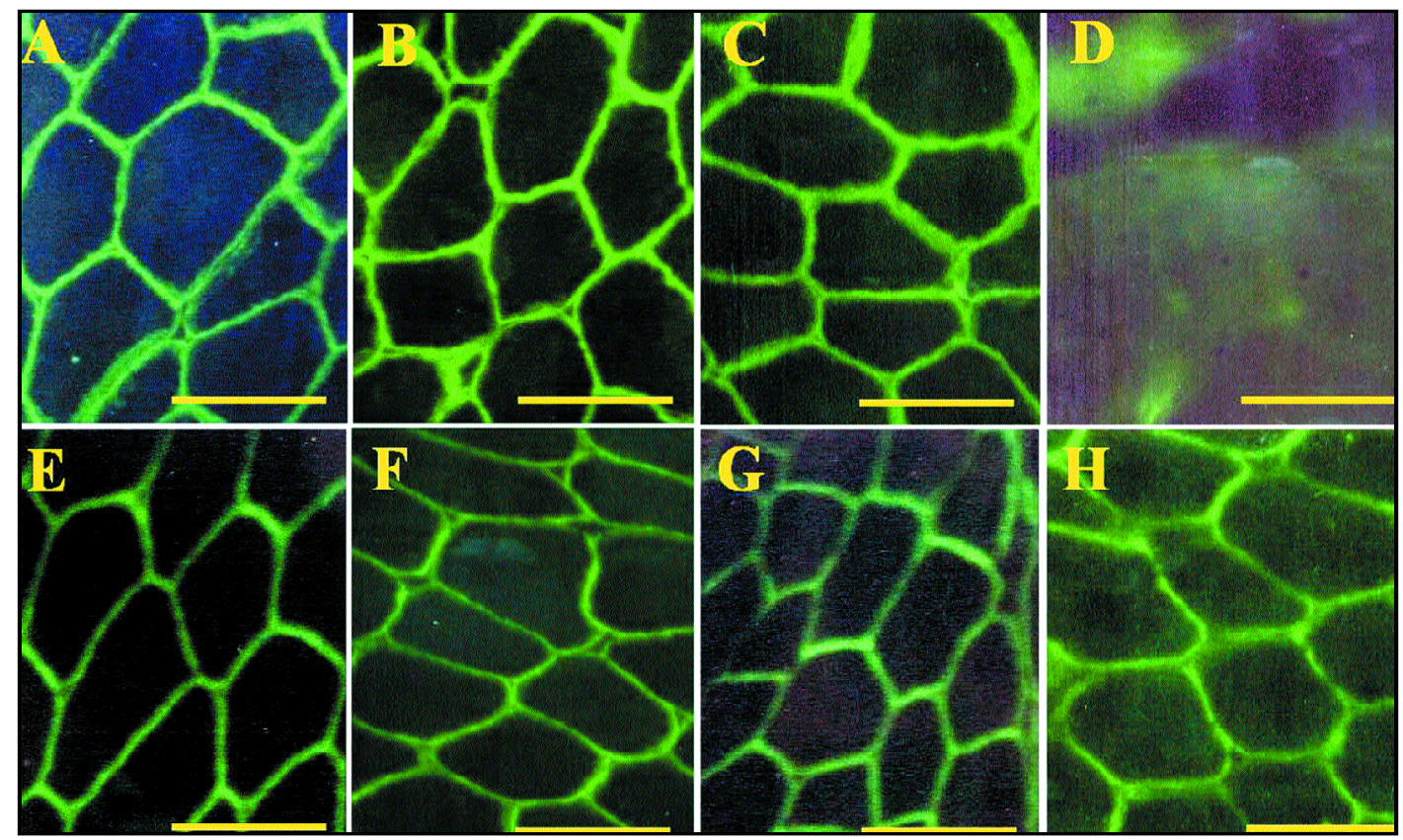

Fig 2. Dyspherlin deficiency (Case 22, immunofluorescence). A, Dystrophin carboxyl terminal; B, Dystrophin amino terminal; C, Dystrophin Rod domain; $D$, Dyspherlin; $E, \alpha$-Sarcoglycan; $F, \beta$-Sarcoglycan; $G, \gamma$-Sarcoglycan; $H, \delta$ Sarcoglycan. (Bar $100 \mu$ in $A, B, C, E, F, G, H ; 25 \mu$ in D). 


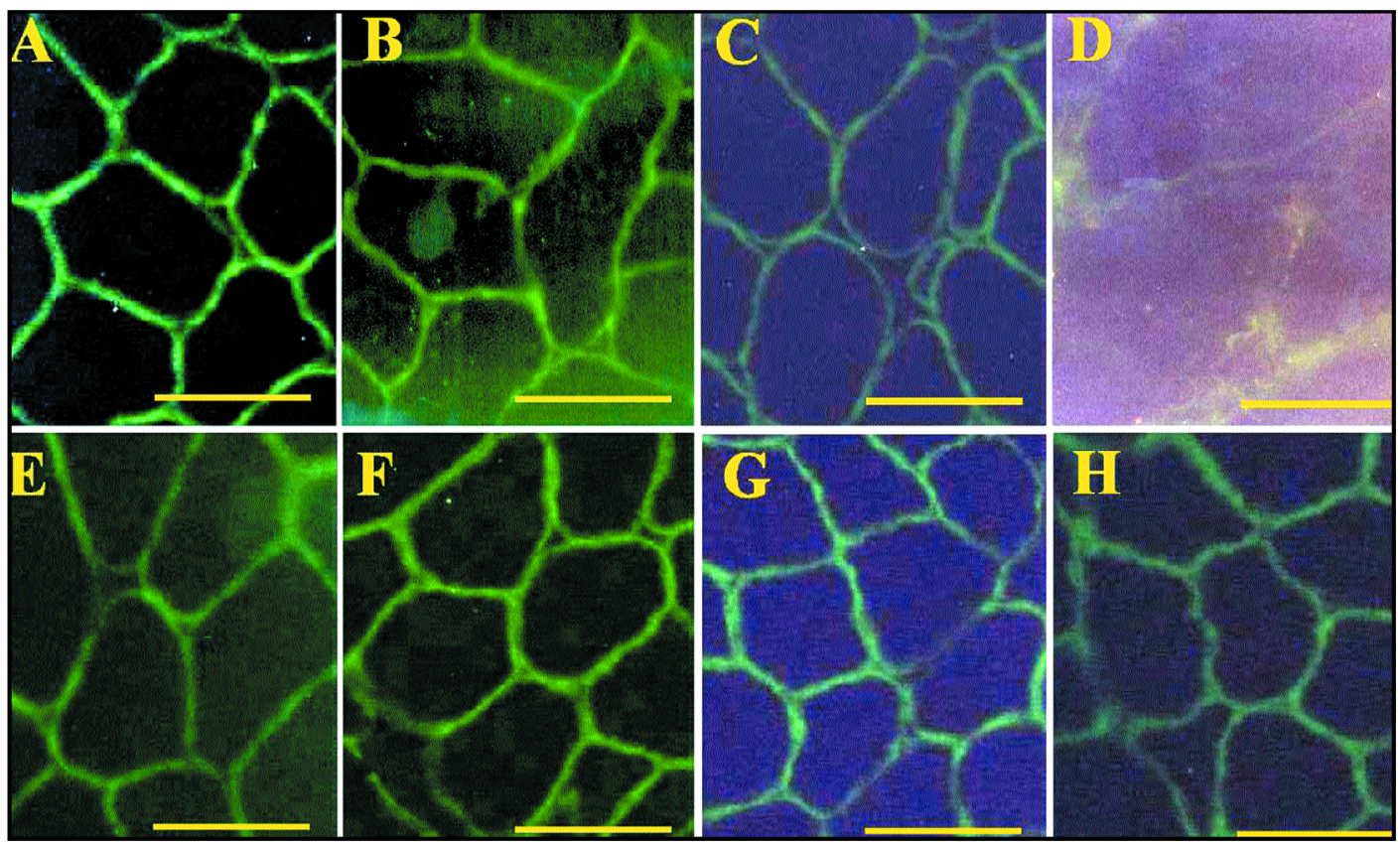

Fig 3. Calpain-3 deficiency (Case 28, immunofluorescence). A, Dystrophin carboxyl terminal; $B$, Dystrophin amino terminal; C, Dystrophin Rod domain; D, Dyspherlin; $E, \alpha$-Sarcoglycan; F, $\beta$-Sarcoglycan; $G, \gamma$-Sarcoglycan; $H, \delta$ Sarcoglycan. (Bar $100 \mu$ in $A, B, C, E, F, G, H ; 25 \mu$ in D).

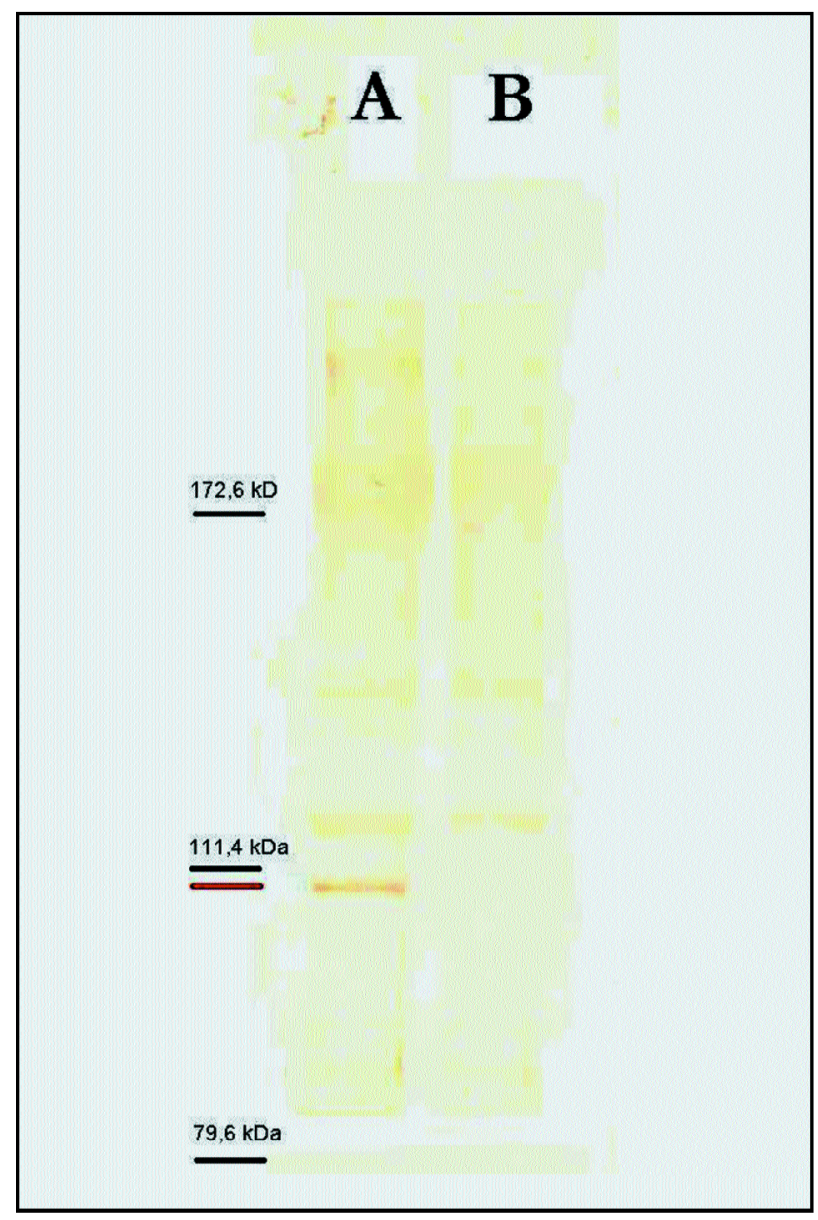

Fig 4. Calpain-3 deficiency (Case 28, Western blot). A, Normal control; $B$, Absent band (Patient).
Small group atrophy was found only in 5 specimens. Type 1 and 2 fibers predominance and vacuoles were uncommon findings. Central nuclei and nuclear clumps were found more frequently in the groups with dysferlin deficiency and also in the non-classified group. Fibers with necrosis were found more frequently in the calpain-3 deficiency group. Basophilic and segmented fibers were more frequently reported in the group with dysferlin deficiency and in the non-classified group. The perivascular inflammatory infiltrates was more common in the group with SG complex deficiency. The increase of fat and fibrous connective tissues was more frequent in dysferlin deficiency patients (group B). The ring fibers, lobulated fibers, and whorled fibers were more common in the group with calpain-3 deficiency. No statistically relevance were found among the ID groups and the several abnormal specific histological findings ( $p>0.05$ ) (Table 7).

Regarding the histological diagnosis, the myopathic pattern was the most common finding in all ID groups. In some of the samples, a suggestion of a neurogenic processes was seen in patients with SG complex (group A), dysferlin (group B) and calpain-3 deficiency (group C). Also, the mixed pattern (myopathy with denervation findings) occurred in the groups with complex SG deficiency and non-classified. No statistical significance was found among the ID groups ( $p>0.05$ ). 
Table 3. Mean age of onset of the symptoms and at evaluation, symptom at presentation by immunoidentifica tion group.

\begin{tabular}{lccccc}
\hline Immunoidentification groups & $\mathrm{A}$ & $\mathrm{B}$ & $\mathrm{C}$ & $\mathrm{D}$ & Total \\
\hline Age of onset & 12.36 & 27.12 & 7.34 & 17.95 & 15.89 \\
& $(1.2-36)$ & $(10-57)$ & $(0.7-17)$ & $(1-39)$ & $(0.7-57)$ \\
Age at evaluation & 19.28 & 33.87 & 17.40 & 27.40 & 23.72 \\
& $(2-43)$ & $(17-61)$ & $(8-24)$ & $(12-42)$ & $(2-61)$ \\
Diseases duration & 6.35 & 6.81 & 10.58 & 9.80 & 7.68 \\
& $(0.7-28)$ & $(1.5-23)$ & $(5-23)$ & $(0.4-25.5)$ & $(0.4-28)$ \\
Symptom at presentation & & & & & \\
Weakness & 3 & 2 & & & 7 \\
$\quad$ Upper limbs & 13 & 6 & 3 & 1 & 29 \\
Lower limbs & 2 & - & 1 & 4 \\
Both limbs & & & & \\
\hline
\end{tabular}

A, sarcoglycanopathy; B, dysferlinopathy; C, calpainopathy; D, not classified.

Table 4. Clinical findings in the neurological examination according the immunoidentification groups.

\begin{tabular}{|c|c|c|c|c|c|}
\hline Immunoidentification groups & $A$ & B & C & D & Total \\
\hline \multicolumn{6}{|l|}{ Muscular atrophy } \\
\hline \multicolumn{6}{|l|}{ Upper limbs } \\
\hline Proximal & 10 & 5 & 5 & 7 & 27 \\
\hline Distal & 4 & - & 2 & 3 & 9 \\
\hline \multicolumn{6}{|l|}{ Lower limbs } \\
\hline Proximal & 11 & 3 & 4 & 6 & 24 \\
\hline Distal & 3 & - & 2 & 3 & 8 \\
\hline Calf Hypertrophy & 4 & - & - & - & 4 \\
\hline \multicolumn{6}{|l|}{ Muscle force graduation (mean) } \\
\hline \multicolumn{6}{|l|}{ Upper limbs } \\
\hline \multirow[t]{2}{*}{ Proximal } & 4.94 & 5.13 & 4.00 & 4.88 & 4.85 \\
\hline & $(2-7)$ & $(3-7)$ & $(3-5)$ & $(3-6)$ & $(2-7)$ \\
\hline \multirow[t]{2}{*}{ Distal } & 6.61 & 6.75 & 5.80 & 6.13 & 6.44 \\
\hline & $(4-7)$ & $(5-7)$ & $(4-7)$ & $(5-7)$ & $(4-7)$ \\
\hline \multicolumn{6}{|l|}{ Lower limbs } \\
\hline \multirow[t]{2}{*}{ Proximal } & 4.83 & 4.63 & 4.20 & 4.50 & 4.64 \\
\hline & $(2-7)$ & $(3-7)$ & $(3-6)$ & $(4-5)$ & $(2-7)$ \\
\hline \multirow[t]{2}{*}{ Distal } & 6.78 & 6.63 & 5.00 & 6.25 & 6.41 \\
\hline & $(5-7)$ & $(5-7)$ & $(4-7)$ & $(4-7)$ & $(4-7)$ \\
\hline Facial weakness & 2 & 1 & 1 & 2 & 6 \\
\hline \multicolumn{6}{|l|}{ Gait type } \\
\hline Normal & 2 & 2 & 1 & 1 & \\
\hline Waddling & 15 & 6 & 4 & 6 & 31 \\
\hline Unable to walk & 1 & - & - & 1 & 2 \\
\hline \multicolumn{6}{|l|}{ Gowers sign } \\
\hline Present & 13 & 6 & 5 & 7 & 31 \\
\hline Unable to perform & 2 & - & - & 1 & 3 \\
\hline \multicolumn{6}{|l|}{ Vignos functional scale } \\
\hline $1-4$ & 17 & 8 & 5 & 7 & 37 \\
\hline 7 & - & - & - & 1 & 1 \\
\hline 9 & 1 & - & - & - & 1 \\
\hline
\end{tabular}

A, sarcoglycanopathy; B, dysferlinopathy; C, calpainopathy; D, not classified. 
Table 5. Mean muscular enzymes by immunoidentification group.

\begin{tabular}{lccccc}
\hline Immunoidentification group & $\mathrm{A}$ & $\mathrm{B}$ & $\mathrm{C}$ & $\mathrm{D}$ & Total \\
\hline Muscular enzymes & & & & \\
CK & 17.39 & 23.85 & 10.45 & 12.26 & 17.41 \\
& $(0-66)$ & $(0.8-46)$ & $(0.4-20.5)$ & $(2.6-23)$ & $(0-66)$ \\
LDH & 1.86 & 1.38 & 0.10 & 0.52 & 1.39 \\
& $(0-11)$ & $(0-3.3)$ & $(0-0.1)$ & $(0-0.2)$ & $(0-11)$ \\
AST & 1.13 & 16.01 & 0.70 & 4.08 & 5.45 \\
& $(0-4)$ & $(0-80)$ & $(0-1.4)$ & $(0-20)$ & $(0-1)$ \\
ALT & 0.68 & 0.37 & 1.00 & 0.16 & 0.55 \\
& $(0-2)$ & $(0-1.3)$ & $(0-2)$ & $(0-0.5)$ & $(0-2)$ \\
Aldolase & 3.21 & - & 0.10 & - & 2.49 \\
& $(0-12)$ & & $(0-0,2)$ & $(0-12)$ \\
\hline
\end{tabular}

A, sarcoglycanopathy; B, dysferlinopathy; C, calpainopathy; D, not classified; CK, Creatine kinase; LDH, Lactic dehydrogenase; AST, Aspartate aminotransferase; ALT, Alanine aminotransferase.

Table 6. Electromyographic pattern by immunoidentificatoin group.

\begin{tabular}{lccccc}
\hline Immunoidentification group & A & B & C & D & Total \\
\hline Electromyography pattern & & & & & \\
Myopathic & 15 & 7 & 2 & 1 & 31 \\
Mixed & 1 & 1 & 1 & 4 \\
\hline
\end{tabular}

A, sarcoglycanopathy; B, dysferlinopathy; C, calpainopathy; D, not classified.

Table 7. Immunoidentification groups and histopathology.

\begin{tabular}{|c|c|c|c|c|c|}
\hline Immunoidentification group & $A$ & B & C & $\mathrm{D}$ & Total \\
\hline Fiber diameter variation & 18 & 8 & 5 & 7 & 38 \\
\hline Type 1 fiber atrophy & 15 & 7 & 5 & 7 & 34 \\
\hline Type 2 fiber atrophy & 14 & 6 & 4 & 5 & 29 \\
\hline Type 1 fiber hypertrophy & 12 & 6 & 4 & 5 & 27 \\
\hline Type 2 fiber hypertrophy & 12 & 6 & 4 & 7 & 29 \\
\hline Atrophic angulated fibers & 10 & 5 & 5 & 4 & 24 \\
\hline Small group atrophy & 1 & 1 & - & 3 & 5 \\
\hline Type 1 fiber predominance & 3 & - & 2 & 1 & 6 \\
\hline Type 2 fiber predominance & 1 & - & - & 1 & 2 \\
\hline Central nuclei & 12 & 7 & 3 & 7 & 29 \\
\hline Nuclear clumps & 2 & 3 & 1 & 3 & 12 \\
\hline Necrotic fibers & 8 & 6 & 4 & 5 & 23 \\
\hline Basophilic fibers & 4 & 3 & 1 & 4 & 12 \\
\hline Segmentation fibers & 7 & 2 & 3 & 4 & 16 \\
\hline Perivascular cellular infiltrates & 8 & 2 & 1 & 2 & 13 \\
\hline Increase fat connective tissue & 8 & 6 & 3 & 4 & 21 \\
\hline Increase connective tissue & 11 & 6 & 3 & 5 & 24 \\
\hline Ringed fibers & 2 & 1 & 2 & 1 & 6 \\
\hline Lobulated fibers & 7 & 4 & 3 & 1 & 15 \\
\hline Whorled fibers & 5 & 3 & 4 & 2 & 14 \\
\hline Vacuoles & - & 1 & 2 & 1 & 4 \\
\hline Rimmed vacuoles & 1 & 1 & - & - & 2 \\
\hline
\end{tabular}

A, sarcoglycanopathy; B, dysferlinopathy; C, calpainopathy; D, non-classified. 


\section{DISCUSSION}

The identification of the forms of LGMD with autosomal recessive inheritance is often difficult to be established, considering the great number of sporadic cases, the lack of convincing data in family history and its great clinical similarity with the Duchenne and Becker muscular dystrophies ${ }^{32}$. These cases had no correlation among the groups of ID and family history, but it was more frequent in the group of the dysferlinopathy ${ }^{33}$. The lack of changes in the ID of the cases of the autosomal dominant trait corroborates the literature data ${ }^{34}$. The great variability in the age of onset difficult the characterization of a typical pattern to each type of LGMD, and the mean age of onset can be common to more than one. We have verified that the cases with dysferlin deficiency showed a later onset ${ }^{33,35}$ and the degrees of deficiency of the sarcoglycan protein complex proteins did not interfere in a meaningful way in the age at onset either ${ }^{36}$.

The classic presentation of the symptoms has been the weakness of the hip-girdle muscles, but can also present as involvement of the shoulder girdle or lower-limb distal muscles, muscular pain, and exercise intolerance ${ }^{20,36,37}$. Some specific patterns can be observed in the calpainopathy (LGMD2A), by involvement of posterior limb-girdle and trunk muscles; in the dysferlinopathy (LGMD2B), by involvement of the posterior compartment of the legs $^{33,38,39}$; in the telethoninopathy (LGMD2G) and titinopathy (LGMD2J), by involvement of the anterior compartment of leg ${ }^{22,34}$. The facial weakness can be observed in advanced stages of the illness in the sarcoglycanopathies (LGMD2C-2F) ${ }^{40}$, and occasionally in the calpainopathy (LGMD2A) and telethoninopathy (LGMD2G) 22,37 . The calf hypertrophy is a common finding among the sarcoglycanopathies but can occasionally be observed in the early stages of the calpainopathy and dysferlinopathy ${ }^{35}$. In our cases the muscular involvement was unspecific, the facial musculature took place in intermediate stages of the disease in all groups of ID, and the calf hypertrophy was observed in the group of SG-complex deficiency.

The muscle enzymes are usually more elevated in the pre-clinical or initial stages of the illness and tend to present gradual decline according to the evolution of the disease, because of the gradual loss of muscular bulk ${ }^{41}$. The increase is more discrete in the autosomal dominant forms (LGMD1A - E) and the telethoninopathy (LGMD2G), but it is generally important in others recessive forms ${ }^{22,34,42}$. Important variations can occur independent of the stage of the disease ${ }^{43}$. The mean serum levels of muscular enzymes were similar for all groups, not being possible to differentiate them.

The progressive loss of the muscle fibers results in the generation of myopathic motor unit potentials in the electromyography. However, neurogenic motor unit potentials can also be observed in areas with clustering or fiber hypertrophy, owing to motor unit remodeling caused by segmentary necrosis process, which can isolate the distal portions of the muscular fibers from the myoneural endplate ${ }^{43}$. The presence of neurogenic motor unit potentials has described in calpainopathy, dysferlinopathy and sarcoglycanopathies ${ }^{39,44,45}$. The dystrophic changes at muscle biopsy, characterized by variation in muscle fiber size, necrotic/regenerating process, and increase of the endomysial and perimysial connective tissue, is the landmark of LGMD ${ }^{46}$.

The variation in muscle fiber size is generally light to moderate degree in the calpainopathy and dysferlinopathy, and more intense in the sarcoglycanopathies ${ }^{33,45}$, in the telethoninopathy (LGMD2G) ${ }^{47}$ and $\mathrm{LGMD}_{2} \mathrm{H}^{48}$. Type 1 fiber predominance can be more intense in the sarcoglycanopathies (LGMD2C-2F) ${ }^{47}$ and calpainopathy (LGMD2A ${ }^{42,49}$. The degenerating and regenerating process do not characterize any specific form in LGMD. The proliferation of the conjunctive and fat connective proliferation usually tends to be more intense in the final stages of the disease ${ }^{46}$. The cellular reactions in the muscular dystrophies are unspecific, and generally vary according to the degree of muscular necrosis, because of the activation and release of the complement ${ }^{46}$. Some perivascular inflammatory reaction can be very similar to inflammatory myopathy, as observed in the sarcoglycanopathies ${ }^{47}$ and dysferlinopathy ${ }^{50}$. The structural alterations in the majority of the autosomal recessive forms of the LGMD are of little intensity and unspecific, with exception of the telethoninopathy (LGMD2G) and the titinopathy (LGMD2I), where there have been reported the formation of rimmed vacuoles ${ }^{23,47}$. Notwithstanding, the existence of rimmed vacuoles is a non-specific finding and has been reported in many neuromuscular diseases, like the inclusion body myositis, spinal muscular atrophies and peripheral neuropathies ${ }^{51}$. The segmentary necrosis processes, can isolate the distal portions of the muscular fibers from the myoneural endplate, and remodeled the motor unit ${ }^{43}$. 
Therefore, angulated atrophic fibers, small groups of atrophic fibers, and nuclear clumps can occasionally be observed in the muscular dystrophies, especially in facioescapulohumeral dystrophy and the LGMD syndromes ${ }^{46}$.

In the sarcoglycanopathies (LGMD2C-2F), the modifications of the SG-complex may also cause a secondary dystrophin deficiency, making the separation from the dystrophinopathies very difficult. Therefore, we chose to include only the cases with normal dystrophin ${ }^{52,53}$. The ID of $\alpha$-SG has been used as the main mark the sarcoglycanopathies, because of the structural alterations of complex SG caused for the mutations in the genes of these protein $s^{52}$. The $\alpha$-sarcoglycan deficiency varies of $9 \%$ to $30 \%$ of the cases, depending on the studied population ${ }^{16,53,54}$. Considering the possibility of the preservation of this marker in the form LGMD2C, we used the remaining ID markers to the proteins of the SG complex. This choice must have contributed to the identification of a larger number of cases when compared to the literature data ${ }^{16,54}$. The alterations of complex SG must be analyzed with caution; therefore they are normally not followed by mutations of the genes of the proteins of complex SG ${ }^{16}$. This fact make possible the occurrence of a secondary deficiency of the complex by other types of mutations, as observed in LGMD2l, where it occur secondary deficiency of $\alpha$-distroglycan and merosin ${ }^{55}$. In $\beta$ and $\gamma$ sarcoglycanopathies (LGMD2E and 2F), the deficiency of proteins of complex SG occurs in a much more uniform way, and does not present a specific pattern $^{16,56,57}$. In the $\alpha$-sarcoglycanopathy (LGMD2D), also a larger correlation with the degree of deficiency of the $\alpha$-sarcoglycan can exist ${ }^{16,58}$. Only in the $\gamma$-sarcoglycanopathy (LGMD2C) the deficiency isolated of protein $\gamma$-SG seems to be a specific result, which suggests a strong correlation of this disease ${ }^{59}$. However, there is a better degree of correlation with mutations of complex SG concerning the cases with important deficiency exist ${ }^{16,52}$.

The immunocytochemical analysis of dysferlin proved to be a difficult technique to interpret, due to the weak fluorescence intensity. The dysferlinopathy corresponds to 5 to $55 \%$ of the LGMD with preservation of the complex $\mathrm{SG}^{32,33,35,53,60}$. The calpain-3, for being a cytoplasmatic enzyme, has been detected only through the western blot technique. The calpain-3 deficiency has been frequently correlated with the protein gene mutations.
However, secondary reductions had been also observed in the cases with mutations in the gene of the dysferlin (LGMD2B) and titin (LGMD2J) ${ }^{23}$. Other alterations also can be caused due to the muscle biopsy storage time, the amount of present protein and by the process of homogenization of muscular tissue. Distortions of the lane of blot difficulties the characterization of the calpain-3 band reduction, probably caused by contamination with the mountant medium. The mutations in the calpain-3 gene have been observed between 9 to $40 \%$ LGMD cases $^{35,53,60,61}$. However, is estimated that $10 \%$ of the mutations of the gene of calpain3 are not detected by the molecular techniques currently used ${ }^{62}$.

The immunocytochemical and western blot analysis were useful methods to classify the LGMD patients. The sarcoglycan deficiency was more frequent, followed of the dysferlinopathy and calpainopathy. Heaven the clinical and laboratory findings were very similar between the ID groups, the dysferlin deficiency patients had more delayed onset, and occurred more in female, and the calpain-3 deficiency patients occurred only in males and had greater impairment in the muscle strength.

\section{REFERENCES}

1. Greenstein RM, Reardon MP, Chan TS. An X/ autosomal translocation in a girl with Duchenne muscular dystrophy (DMD): evidence for DMD gene localization. Pediatr Res 1977;11:457.

2. Francke U, Ochs HD, De Martinville B, et al. Minor XP21 chromosome deletion in a male associated with expression of Duchenne muscular dystrophy, chronic granulomatous disease, retinitis pigmentosa, and McLeod syndrome. Am J Hum Genet 1985;37:250-267.

3. Kunkel LM, Monaco AP, Middleswoth W, Ochs HD, Latt AS. Specific cloning of DNA fragments absents from the DNA of male patient with an X chromosome deletion. Proc Natl Acad Sci 1985;82:4778-4782.

4. Koenig M, Hoffmann EP, Beterlson CJ, Monaco AP, Feener C, Kunkel LM. Complete cloning of Duchenne muscular dystrophy (DMD) cDNA and preliminary genomic organization of the DMD gene in normal and affected individuals. Cell 1987;50:509-517.

5. Hoffman EP, Brown RH, Kunkel LM. Dystrophin: the protein product of the Duchenne muscular dystrophy locus. Cell 1987;51:919-928.

6. Campbell KP, Khal SD. Association of dystrophin and an integral membrane glycoprotein. Nature 1989;338:259-262.

7. Ervasti JM, Campbell KP. Membrane organization of the dystrophinglycoprotein complex. Cell 1991;66:1121-1131.

8. Yoshida M, Ozawa E. Glycoprotein complex anchoring dystrophin to sarcolemma. J Bichem 1990;108:748-752

9. Tinsley AM, Blake DJ, Roche A, et al. Primary structure of dystrophinrelated protein. Nature 1992;360:591-593.

10. Campbell KP. Three muscular dystrophies: loss of cytoskeleton-extracelular matrix linkage. Cell 1995;80:675-679.

11. Matsumura K, Campbell KP. Deficiency of dystrophin-associated proteins: a common mechanism leading to muscle cell necrosis in severe childhood muscular dystrophies. Neuromusc Disord 1993;3:109-118.

12. Noguchi S, McNally EM, Ben Othmane K, et al. Mutations in the dystrophin-associated protein ?-sarcoglycan in chromosome 13 muscular dystrophy. Science 1995;270:819-822.

13. Roberds S, Leturcq F, Allamand V, et al. Missense mutations in the adhalin gene linked to autosomal recessive muscular dystrophy. Cell 1994;78:625-633. 
14. Bönnemann CG, Modi R, Noguchi S, et al. Beta sarcoglycan (A3b) mutations cause autosomal recessive muscular dystrophy with loss of the sarcoglycan complex. Nature 1995;11:266-273.

15. Passos-Bueno MR, Moreira ES, Vainzof M, MarieSK, Zatz M. Linkage analysis in autosomal recessive limb-girdle muscular dystrophy (AR LGMD) maps a sixth form to 5q33-34 (LGMD2F) and indicates that there is at least one more subtype of AR LGMD. Hum Mol Genet 1996;5:818-820.

16. Duggan DJ, Gorospe R, Fanin M, Hoffman EP, Angelini C. Mutations in the sarcoglycan genes in patients with myopathy. N Engl J Med 1997;336:618-624.

17. Bashir R, Strachan T, Keers S, et al. A gene for autosomal recessive limbgirdle muscular dystrophy maps to chromosome 2p. Hum Mol Genet 1994;3:455-457.

18. Speer MC, Yamoaka LH, Gilchrist JH, et al. Confirmation of genetic heterogeneity in limb-girdle muscular dystrophy: linkage of an autosomal dominant form to chromosome 5q. Am J Hum Genet 1992;50:1211-1217.

19. Richard I, Broux O, Allamand V, et al. Mutations in the proteolytic enzyme calpain 3 cause limb-girdle muscular dystrophy type 2A. Cell 1995;81:27-40.

20. Weiler T, GreenbergCR, Zelinski T. A gene for autosomal recessive limbgirdle muscular dystrophy in Manitoba Hutterites maps to chromosome region 9q31-q33: evidence for another limb-girdle muscular dystrophy locus. Am J Hum Genet 1998;63:140-147.

21. Driss A, Amouri C, Hamida CB, et al. A new locus for autosomal recessive limb-girdle muscular dystrophy in a large consanguineous Tunisian family maps to chromosome 19q13.3. Neuromusc Disord 2000;10:240-246.

22. Moreira ES, Wiltshire TJ, Faulkner G, et al. Limb-girdle muscular dystrophy type $2 \mathrm{G}$ is caused by mutation in the gene encoding the sarcomeric protein telethonin. Nat Gene 2000;24:163-166.

23. Haravuori H, Vihola A, Straub V, et al. Secondary calpain3 deficiency in 2q-linked muscular dystrophy: Titin is the candidate gene. Neurology 2001;56:869-877.

24. Hauser MA, Horrigan SK, Salamikangas P, et al. Myotilin is mutated in limb-girdle muscular dystrophy 1A. Hum Mol Genet 2000;9:21412147.

25. Palenzuela L, Andreu AL, Gamez J, et al. Anovel autosomal dominant limb-girdle musclar dystrophy (LGMD 1F) maps to 7q32.1-32.2. Neurology 2003;61:404-495.

26. Muchir A, Bonne G, van der Kooi AJ, et al. Identification of mutations in the gene encoding lamins $\mathrm{A} / \mathrm{C}$ in autosomal dominant limb girdle muscular dystrophy with atrioventricular conduction disturbances. Hum Mol Genet 2000;9:1453-1459.

27. Mendell JR, Florence J, Manual muscle testing. Muscle Nerve 1990;13:16-20.

28. Vignos PJ, Spencer GE, A rchibald KC. Management of progressive muscular dystrophy of childhood. JAMA 1963;184:89-96

29. Dubowitz V. Muscle biopsy: a practical approach. London: Bailliüre Tindall, 1985.

30. Werneck LC, Bonilla E. Immunohistochemical alterations of dystrophin in congenital muscular dystrophy. Arq Neuropsiquiatr 1995;53:416-423.

31. Spencer MJ, Tidball JG, Anderson LVB, et al. Absence of calpain 3 in a form of limb-girdle muscular dystrophy (LGMD2A). J Neurol Sci 1997; 146:173-178.

32. Dinçer P, Leturcq F, Richard I, et al. A biochemical, genetic, and clinical survey of autosomal recessive limb girdle muscular dystrophies in Turkey. Ann Neurol 1997;42:222-229.

33. Soares CN, Freitas MR, Nascimento OJ, et al. Myopathy of the distal lower limbs: the clinical variant of Miyoshi. A rq Neuropsiquiatr 2003;61:946-949.

34. Bushby KMD. The limb-girdle muscular dystrophies: multiple genes, multiple mechanisms. Hum Mol Genet 1999;10:1875-1882.

35. Passos-Bueno MR, Vainzof M, Moreira ES, Zatz M. Seven autosomal recessive limb-girdle muscular dystrophies in the Brazilian population: from LGMD2A to LGMD2G. Am J Med Genet 1999;82:392-398.

36. Morandi L, Barresi R, Di Blasi C, et al. Clinical heterogeneity of adhalin deficiency. Ann Neurol 1996;39;196-202.

37. Chou FL, Angelini C, Daentl D, et al. Calpain III mutation analysis of a heterogeneous limb-girdle muscular dystrophy muscular dystrophy population. Neurology 1999;52:1015-1020.

38. Weiler T, Greenberg CR, Nylen E, et al. Limb-girdle muscular dystrophy and Miyoshi myopathy in an aboriginal Canadian kindred map to LGMD2B and segregate with the same haplotype. Am J Hum Genet 1996;59:872-878.
39. Fardeau M, Hillaire D, Mignard C, et al. Juvenil limb-girdle muscular dystrophy: clinical, histopathological and genetic data from a small community living in Reunion Island. Brain 1996;119:295-308.

40. Duggan DJ, Hoffman EP. Autosomal recessive muscular dystrophy and mutations of the sarcoglycan complex. Neuromusc Disord 1996;6:475-482.

41. Emery AEH. Duchenne muscular dystrophy, $2^{\text {nd }}$ ed. Oxford: Oxford Univ Press, 1993.

42. Urtasun M, Sáenz A, Roudant C, et al. Limb-girdle muscular dystrophy in Guipúzcoa (Basque Contry, Spain). Brain 1998;121:1735-1747.

43. Sonoo M. New attempts to quantify concentric needle electromyography. Muscle Nerve. 2002;S11:S98-S102.

44. Mahjneh I, Bushby K, Pizzi A, Bashir R, Marconi G. Limb-girdle muscular dystrophy: a follow-up study of 79 patients. Acta Neurol Scand 1996;94:177-189.

45. Ben Jelloun-Dellagi S, Chaffey P, Ben Hamida CH, et al. Presence of normal dystrophin in Tunisian severe childhood autosomal recessive muscular dystrophy. Neurology 1990;40:1903.

46. Walton JN, Nattrass FJ. On the classification, natural history and treatment of myopathies. Brain $1954 ; 77: 169-231$.

47. Moreira ES, Vainzof M, Marie SK, Sertié AL, Zatz M, Passos-Bueno MR. The seventh form of autosomal recessive limb-girdle muscular dystrophy is mapped to 17q11-12. Am J Hum Genet 1997;61:151-159.

48. Shokeir MHK, Kobrinsky NL. Autosomal recessive muscular dystrophy in Manitoba Hutterites. Clin Genet 1976;9:197-202.

49. Chae J, Minami N, Jin Y, et al. Calpain 3 gene mutations: genetic and clinical-pathologic findings in limb-girdle muscular dystrophy. Neuromusc Disord 2001;11:547-555.

50. McNally EM, Chantal TL, Rosenmann H, et al. Splicing mutation in dysferlin produces limb-girdle muscular dystrophy with inflammation. Am J Med Genet 2000;91:305-312.

51. Scola RH, Werneck LC, Franco CRC. Cytoplasmic inclusion bodies: a study in several diseases and a review of the literature. Arq Neuropsiquiatr 1996;54:245-259.

52. Vainzof M, Passos-Bueno MR, Canovas M, et al. The sarcoglycan complex in the six autosomal recessive limb-girdle muscular dystrophies. Hum Mol Genet 1996;5:1963-1969.

53. Shilling CJ, Wicklund MP, Moore SA, et al. Establishing the prevalence of LGMD genotypes in North America: an ongoing multi-center collaborative study. Neurology 2004;7(S5):A412.

54. Hayashi YK, Mizuto Y, Yoshida M, Nonaka I, Ozawa E, Arahata K. The frequency of patients with 50-kd dystrophin-associated glycoprotein (50DAG or adhalin) deficiency in a muscular dystrophy patient population in Japan: immunocytochemical analysis of 50DAG, 43DAG, dystrophin, and utrophin. Neurology 1995;45:551-554.

55. Brockington M, Blake DJ, Prandini $P$, et al. Mutations in the fukutinrelated protein gene (FKRP) cause a form of congenital muscular dystrophy with secondary laminin ?2 deficiency and abnormal glycosylation of ?-dystroglycan. Am J Hum Genet 2001;69:1198-1209.

56. Bönnemann CG, Passos-Bueno MR, McNally EM, et al. Genomic screening for beta-sarcoglycan gene mutations: missense mutations may cause severe limb-girdle muscular dystrophy type 2E (LGMD 2E). Hum Mol Genet 1996;5:1956-1961.

57. Moreira ES, Vainzof M, Marie SK, Nigro V, Zatz M, Passos-Bueno MR. A first missense mutation in the delta sarcoglycan gene associated with a severe phenotype and frequency of limb-girdle muscular dystrophy type 2F (LGMD2F) in Brazilian sarcoglycanopathies. J Med Genet 1998;35:951-953.

58. Eymard B, Romero NB, Leturcq F, et al. Primary adhalinopathy (?-sarcoglycanopathy): clinical, pathologic, and genetic correlation in 20 patients with autosomal recessive muscular dystrophy. Neurology 1997;48:12271234.

59. Vorgerd M, Gencik M, Mortier J, Epplen JT, Malin JP, Mortier W. Isolated loss of $\gamma$-sarcoglycan: diagnostic implications in autosomal recessive limbgirdle muscular dystrophies. Muscle Nerve 2001;24:421-424.

60. Argov Z, Sadeh M, Mazor K, et al. Muscular dystrophy due to dysferlin deficiency in Libyan Jews: clinical and genetic features. Brain 2000;123:1229-1237.

61. Minami N, Nishino I, Kobayashi, Ikezoe K, Yu-ichi G, Nonaka I. Mutation of calpain 3 gene in patients with sporadic limb-girdle muscular dystrophy in Japan. J Neurol Sci 1999;171:31-37.

62. Fanin M, Pegoraro E, Matsuda-Asada C, Brown RH, Angelini C. Calpain-3 and dysferlin protein screening in patients with limb-girdle muscular dystrophy. Neurology 2001;56:660-665. 